J. Perinat. Med.

2 (1974) 196

\section{Prediction of perinatal mortality in early pregnancy}

\author{
C. Rumeau-Rouquette, M. Kaminski, J. Goujard
}

Section Maternité Pédiatrie de l'Institut National de la Santé et de la Recherche Médicale, Le Vesinet, France

Unité de Recherches Statistiques de l'Institut

National de la Santé et de la Recherches Médicale, Villejuif, France

Received October 1, 1973. Accepted April 16, 1974.
The detection of high-risk pregnancies has become one of the major concerns of physicians and midwives in charge of pregnant women. Detection must be made very early, and it would be highly desirable for certain factors of risk to be discovered before the beginning of pregnancy, and even before any pregnancy in any given woman.

In the work reported here, our objective was to predict perinatal mortality during the first three months of pregnancy in order to discover the groups at risk requiring particular care. Predictions will be based not only on pathological findings, but also on characteristics, the importance of which is sometimes less well known, such as age, social and economic status, and circumstances of life during pregnancy. On the basis of an analytical study of these factors, an attempt at predicting stillbirth and neonatal death is made.

\section{Subjects and method}

This study was based on a prospective survey carried out by the "Maternity and Pediatric Section" of I. N. S. E. R. M. in collaboration with the "Statistical Research Unit" of I. N. S. E. R. M. and the Obstetric Departments of Hospitals of the Assistance Publique in Paris. It includes 18,000 pregnancies. The procedure was as follows:

- during the first three months of pregnancy, a detailed interview of women concerning pathological antecedents, general circumstances of life and all pathology observed at the beginning of pregnancy together with treatment given; general and obstetric examination.

- blood specimen during the third and sixth months and in the umbilical cord at birth; the frozen sera were subjected to serological analysis.

\section{Curriculum vitae}

Claude Rumeau-RouquetTE is a medical doctor and an epidemiologist. Since 1963 she has beaded the Maternal and Cbild Health Section of I. $N$. S. E. R. M. Her team of young researchers bas realized several regional and national studies on the etiology of neonatal disease, notably in the areas of prematurity, congenital malformations and fetal

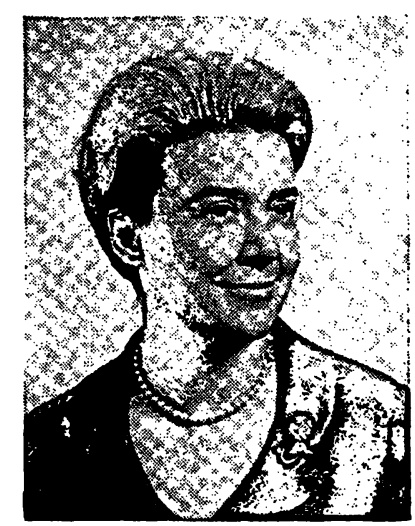
distress.

Doctor Rumeau-RovQuetre teacbes epidemiologj in a medical school in Paris. She is the author of a manual on epidemiological methods.

- a retrospective record made at birth indicating the main pathological changes observed during the second and third trimesters.

- systematic examination of infants during the neonatal period.

- supervision of some groups of children during the first year.

This survey is at present undergoing statistical analysis, and several findings have already been published concerning the role of drugs and viral diseases in the etiology of congenital malformations $[1,3,4,8]$, the relation between metrorrhagia during the first three months of pregnancy and some malformations [6] and the prediction of prematurity and birth weight [2].

Before going into the details, we shall refer briefly the selection of the population. As already stated, the survey was made on women attending public hospitals, the interviews being done by physicians of I. N. S. E. R. M.; it was impossible for the latter to include all patients in the study. They therefore made a selection which we asked them to do without any a priori notions. The group is therefore the result of a double selection and obviously 
not representative of the population of Paris. However, it should be remarked that selections were made long before the outcome of pregnancy and cannot have a direct influence on the associations existing between the factors studied and the outcome of pregnancy. This is one of the advantages of prospective surveys that we treated at greater length in previous studies [5].

A more serious fact is that 5,500 women, or $30 \%$, did not come for confinement to the hospitals in which the survey was made, and this additional selection, which happened frequently at the time of confinement, might depend on the outcome of the pregnancy and on the factors of risk. It is therefore very important to reduce its effects by making a special enquiry concerning the women who have been lost from view. This enquiry is at present going on and the results will be published later. However, the first findings show that this problem does not have an important influence on the conclusions, and we have decided to publish them for women who were confined in the hospitals concerned in the survey (there is no difference in the perinatal death rates of the two groups of women).

The present analysis was realized on only the first cases collected and includes only metropolitan women; (twin pregnancies were excluded). They gave birth to 7,032 infants, 74 of which were stillborn and 73 died during the first six days of life. The still-birth rate is a little lower than that observed in France during the same period; we compared this rate with the rate for the total number of confinements observed in the hospitals concerned in the survey, and it is very similar. Hence the selection of the women referred to above does not seem to interfere with our conclusions.
In this analysis, we considered stillbirth and neonatal mortality separately. This proved entirely justified since the two phenomena are not always related to the same factors. On the other hand, we did not go into the details of the causes, except at the end, when putting forward our hypotheses that will have to be verified later on a larger number of cases.

\section{Results}

\subsection{General characteristics and circum- stances of life}

\subsubsection{Family status, maternal age and number of previous pregnancies}

Unwed mothers have a higher perinatal death rate than married women: this applies to both categories of perinatal mortality although it is significant only for neonatal mortality (Tab. I).

Maternal age has a well known influence, with a higher mortality rate for very young women, a minimum between the ages of 21 and 29 and a continual rise after the age of 30 . The study of birth rank indicates the same tendency for stillbirth with a higher rate for primigravida women, a minimum for secundigravida women and a progressive rise afterwards. But the neonatal death rate increases regularly with the number of pregnancies.

Tab. I. Death rate per 1000 births in relation to family status, age and number of previous pregnancies.

\begin{tabular}{|c|c|c|c|c|c|c|c|}
\hline & \multirow{2}{*}{$\begin{array}{l}\text { Number } \\
\text { of cases }\end{array}$} & \multicolumn{2}{|c|}{ Stillbirth } & \multicolumn{2}{|c|}{ Neonatal mortality } & \multicolumn{2}{|c|}{ Perinatal mortality } \\
\hline & & number & rate & number & rate & number & rate \\
\hline Unmarried mothers & 904 & 13 & 14.4 & 17 & 19.1 & 30 & 33.2 \\
\hline Married mothers & 5918 & 58 & 9.8 & 48 & $\begin{array}{l}8.2 \\
*\end{array}$ & 106 & $\begin{array}{c}17.9 \\
*\end{array}$ \\
\hline Age $\leqq 20$ years & 1043 & 9 & 8.6 & 13 & 12.6 & 22 & 21.1 \\
\hline $21-29$ years & 3982 & 26 & 6.5 & 28 & 7.1 & 54 & 13.6 \\
\hline $30-39$ years & 1800 & 33 & 18.3 & 30 & 17.0 & 63 & 35.0 \\
\hline 40 and + years & 102 & 3 & $\begin{array}{c}29.4 \\
* *\end{array}$ & 2 & $\begin{array}{c}20.2 \\
* *\end{array}$ & 5 & 49.0 \\
\hline
\end{tabular}

Number of previous

pregnancies

\begin{tabular}{lccccccc}
0 & 2208 & 21 & 9.5 & 14 & 6.4 & 35 & 15.9 \\
1 & 2115 & 14 & 6.6 & 15 & 7.1 & 29 & 13.7 \\
2 & 1271 & 14 & 11.0 & 13 & 10.3 & 27 & 21.2 \\
3 & 656 & 13 & 19.8 & 13 & 20.2 & 26 & 39.6 \\
4 and + & 782 & 12 & 15.3 & 18 & 23.4 & 30 & 38.4 \\
& & & $*$ & & $* * *$ & & $* * *$ \\
\hline
\end{tabular}

Significance: $* \mathrm{p}<0.05 ; \quad * * \mathrm{p}<0.01 ; \quad * * * \mathrm{p}<0.001$

Notice: Here the perinatal mortality rate per 1000 births is not the sum of the stillbirth rate and nconatal mortality rate, the stillbirth rate is given per 1000 births, whereas the neonatal mortality rate is calculated per 1000 .liveborn infants. 
$\cdot 1$

Tab. II. Mortality rate per 1000 births in relation to number of pregnancies and family status.

\begin{tabular}{|c|c|c|c|c|c|c|c|}
\hline \multirow[b]{2}{*}{. } & \multirow{2}{*}{$\begin{array}{l}\text { Number } \\
\text { of cases }\end{array}$} & \multicolumn{2}{|c|}{ Stillbirth } & \multicolumn{2}{|c|}{ Neonatal mortality } & \multicolumn{2}{|c|}{ Perinatal mortality } \\
\hline & & number & rate & number & rate & number & rate \\
\hline \multicolumn{8}{|c|}{ No previous pregnancy } \\
\hline Unmarried & 451 & 8 & 17.7 & 7 & 15.8 & 15 & 33.2 \\
\hline Married & 1741 & 13 & 7.5 & 7 & 4.1 & 20 & 11.4 \\
\hline & & & $*$ & & $* *$ & & $* *$ \\
\hline \multicolumn{8}{|c|}{1 or 2 previous } \\
\hline Unmarried & 289 & 3 & 10.4 & 5 & 17.5 & 8 & 27.6 \\
\hline Married & 3040 & 25 & 8.2 & 22 & 7.3 & 47 & 15.4 \\
\hline \multicolumn{8}{|c|}{$\begin{array}{l}\text { More than } 2 \text { previous } \\
\text { pregnancies }\end{array}$} \\
\hline Unmarried & 164 & 2 & 12.2 & 5 & 30.9 & 7 & 42.6 \\
\hline Married & 1137 & 20 & 17.6 & 19 & 17.0 & 39 & 34.3 \\
\hline
\end{tabular}

Tab. III. Stillbirth rate per 1000 births in relation to age and number of previous pregnancies.

\begin{tabular}{|c|c|c|c|c|c|c|c|c|c|}
\hline \multirow{3}{*}{ Age } & \multicolumn{8}{|c|}{ Number of previous pregnancies } & \multirow[b]{3}{*}{ (3) } \\
\hline & & 0 & & & $1-2$ & & & and + & \\
\hline & (1) & $(2)$ & (3) & (1) & $(2)$ & (3) & (1) & (2) & \\
\hline$\leqq 20$ years & 665 & 6 & 9.0 & 361 & 3 & 8.3 & $(17)$ & 0 & s. $\mathrm{n}$. \\
\hline $21-29$ years & 1275 & 12 & 9.4 & 2129 & 7 & 3.3 & 578 & 7 & 12.1 \\
\hline $30-39$ years & 225 & 3 & 13.1 & 834 & 16 & 19.2 & 741 & 14 & 18.9 \\
\hline 40 and $t$ & (5) & 0 & s. $\mathrm{n}$. & $(18)$ & 1 & s. n. & 79 & 2 & 25.3 \\
\hline
\end{tabular}

s. n.; number of cases too small (1): number of cases

(2): number of stillbirths

(3): stillbirth rate per 1000 births

As these three characteristics are closely related one to the other, we studied their respective parts. Tab. II shows that family status has an influence particularly for primigravida women. We also found similar results for age: Family status has an influence particularly for young women.

Comparison of risks related to age and parity confirms the respective part of these two characteristics: The lowest stillbirth rate is observed in women aged 21 to 29 who had one or two previous pregnancies $(3.3 \%$ ), primigravida womon and those under 20 showing intermediate rates while the highest rates are observed for multiparous women over 30 (Tab. III).

\subsubsection{Socio-professional characteristics}

We took into account the father's occupation for estimating the social status of the family; the results in Tab. IV show that stillbirth rate is low in the executive class, intermediate for managerial classes, craftsmen, employees and the working class, and very high for unskilled laborers and service staff; these differences are significant. The results are a little different for neonatal mortality rate; it is very low in the executive class, whereas in the other three categories it is a little higher but identical: The rates are not significantly different. 
Tab. IV. Daath rate per 1000 births in relation to father's occupation.

\begin{tabular}{|c|c|c|c|c|c|c|c|}
\hline & \multirow{2}{*}{$\begin{array}{l}\text { Number } \\
\text { of cases }\end{array}$} & \multicolumn{2}{|c|}{ Stillbirth } & \multicolumn{2}{|c|}{ Neonatal mortality } & \multicolumn{2}{|c|}{ Perinatal mortality } \\
\hline & & number & rate & number & rate & number & rate \\
\hline Executives & 557 & 3 & 5.4 & 2 & 3.6 & 5 & 9.0 \\
\hline $\begin{array}{l}\text { Managerial staff and } \\
\text { craftsmen }\end{array}$ & 3692 & 39 & 10.6 & 37 & 10.1 & 76 & 20.6 \\
\hline $\begin{array}{l}\text { Employees, working } \\
\text { class }\end{array}$ & 1960 & 15 & 7.7 & 24 & 12.3 & 39 & 19.9 \\
\hline $\begin{array}{l}\text { Unskilled laborers } \\
\text { and service staff }\end{array}$ & 527 & 11 & $\begin{array}{c}20.9 \\
*\end{array}$ & 6 & 11.6 & 17 & 32.3 \\
\hline
\end{tabular}

We had some information about the mother's work, we knew whether the woman had an occupation, whether she worked standing or sitting, or during the day or at night. None of these characteristics is significantly related to perinatal mortality. However, these findings are based on observations made at the beginning of pregnancy, and it is possible that working conditions were changed for some women because of the appearance of alarming signs; we took these changes into account in later studies.

\subsubsection{Tobacco use}

Numerous authors have pointed out the relation between tobacco use and hypotrophy, but fewer found an association between perinatal mortality and tobacco [7].
Tab. V shows the results we obtained:

a) Stillbirth rate is significantly higher in smokers, but neonatal death rate does not differ significantly;

b) When smokers are divided into two groups according to whether they stopped smoking at the beginning of pregnancy or not, there is an excess of stillborn infants only in women who continue to smoke;

c) The quantity of tobacco smoked does not seem to have any influence;

d) Inhalation, however, is a risk factor.

The objection may be raised that smokers and non-smokers have many different characteristics; in fact, in our population, the smokers are younger, taller and slimmer, have fewer children and belong to more well-to-do classes. We made the

Tab. V. Death rate per 1000 births in relation to tobacco use.

\begin{tabular}{|c|c|c|c|c|c|c|c|}
\hline & \multirow{2}{*}{$\begin{array}{l}\text { Number } \\
\text { of cases }\end{array}$} & \multicolumn{2}{|c|}{ Stillbirth } & \multicolumn{2}{|c|}{ Neonatal mortality } & \multicolumn{2}{|c|}{ Perinatal mortality } \\
\hline & & number & rate & number & rate & number & rate \\
\hline Non-smokers & 5791 & 50 & 8.6 & 57 & 9.9 & 107 & 18.4 \\
\hline \multirow[t]{2}{*}{ Smokers } & 1139 & 23 & 20.2 & 15 & 13.4 & 38 & 33.3 \\
\hline & & & $* * *$ & & & & $* *$ \\
\hline Non smokers & 5791 & 50 & 8.6 & 57 & 9.9 & 107 & 18.4 \\
\hline Smokers who stop & 348 & 1 & 2.9 & 6 & 17.2 & 7 & 20.1 \\
\hline \multirow{3}{*}{$\begin{array}{l}\text { Smokers who con- } \\
\text { tinue }\end{array}$} & & & & & & & \\
\hline & 789 & 22 & 27.9 & 9 & 11.7 & 31 & 39.2 \\
\hline & & & $* * *$ & & & & $* * *$ \\
\hline \multicolumn{8}{|l|}{$\begin{array}{l}\text { Quantity smoked since } \\
\text { last menstrual period }\end{array}$} \\
\hline $1-9$ cigarettes daily & 433 & 12 & 27.7 & 6 & 14.2 & 18 & 41.5 \\
\hline 10 cigarettes or more & 356 & 10 & 28.1 & 3 & 8.6 & 13 & 36.6 \\
\hline \multicolumn{8}{|l|}{$\begin{array}{l}\text { Inhalation since last } \\
\text { menstrual period }\end{array}$} \\
\hline No & 358 & 5 & 14.1 & 6 & $17: 1$ & 11 & 31.0 \\
\hline \multirow[t]{2}{*}{ Yes } & 411 & .6 & 38.9 & 3 & 7.5 & 19 & 46.2 \\
\hline & & & * & & & & \\
\hline
\end{tabular}


necessary adjustments so that the two groups would be more comparable, but the association between tobacco use and stillbirth persists. Furthermore, smokers who stop smoking during pregnancy have more or less the same social characteristics as those who continue, yet Tab. V shows that the stillbirth rates in the two groups are very different.

These results obviously call for new investigations as it is necessary to determine whether tobacco plays a direct part in the process causing death in utero or if it is merely an indication of risk for a woman who continues to smoke, and at the same time does not take the necessary care during her pregnancy.

\subsection{Outcome of previous pregnancies}

The outcome of previous pregnancies is known as being particularly important in predicting or explaining the outcome of the current pregnancy. Tab. VI shows that there is an extremely im- portant relationship between the stillbirth rate and the occurence of stillborn infants during the previous pregnancies. Comparisons were made with women having given birth to living children weighing more than 2,500 grammes as a basic reference: the stillbirth rate is low $(5.1 \%)$. If the woman has had one or more stillborn children during her previous pregnancies, the stillbirth rate rises up to $77.6 \%$ for the current pregnancy, i. e. 13 times higher, which is a very significant difference. If the woman has had children weighing 2,500 grammes or less but no stillborn infants, the stillbirth rate is $15.7 \%$ and the difference is significant. In cases of abortion (spontaneous or provoked) the stillbirth rate is $9 \%$ which is not different from the reference population.

A study of the last previous pregnancy shows similar results, that are even more clear-cut than those given above.

Results are considerably different for neonatal death rate; Tab. VI shows that there is one

Tab. VI. Death rate per 1000 births in relation to the outcome of the previous pregnancies (N.S. = not significantly different).

\begin{tabular}{|c|c|c|c|c|c|c|c|}
\hline Obstetrical antecedents & $\begin{array}{l}\text { Number } \\
\text { of cases }\end{array}$ & number & $\begin{array}{l}\text { Stillbirth } \\
\text { rate }\end{array}$ & $\begin{array}{l}\text { com- } \\
\text { parison } \\
\text { with } \\
\text { control } \\
\text { group }\end{array}$ & $\begin{array}{l}\text { Neor } \\
\text { number }\end{array}$ & $\begin{array}{l}\text { al mor } \\
\text { rate }\end{array}$ & $\begin{array}{l}\text { compa- } \\
\text { rison } \\
\text { with } \\
\text { control } \\
\text { group }\end{array}$ \\
\hline $\begin{array}{l}\text { 1st group: } \\
\text { At least one stillborn child }\end{array}$ & 219 & 17 & 77.6 & \multicolumn{4}{|c|}{ 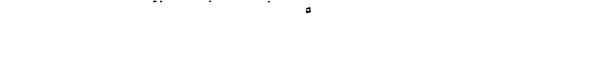 } \\
\hline $\begin{array}{l}\text { 2nd group: } \\
\text { No stillborn children but at least one } \\
\text { child weighing } \leqq 2500 \mathrm{~g}\end{array}$ & 575 & 9 & 15.7 & $*$ & 15 & 26.5 & $* * *$ \\
\hline $\begin{array}{l}\text { 3rd group: } \\
\text { No stillborn children or children } \\
\text { weighing } \leqq 2500 \mathrm{~g} \text { but at least one } \\
\text { abortion }\end{array}$ & 1267 & 13 & 10.3 & N. S. & 17 & 13.6 & N. S. \\
\hline $\begin{array}{l}\text { Control group: } \\
\text { All children born alive and weighing } \\
\text { more than } 2500 \mathrm{~g}\end{array}$ & 2763 & 14 & 5.1 & & 24 & 8.7 & \\
\hline $\begin{array}{l}\text { Outcome of the last previous } \\
\text { pregnancy: }\end{array}$ & & & & & & & \\
\hline Abortion & 915 & 11 & 12.0 & & 11 & 12.2 & \\
\hline Stillbirth & 88 & 11 & 125.0 & $* *$ & 0 & .0 & N. S. \\
\hline Living child $\leqq 2500 \mathrm{~g}$ & 281 & 4 & 14.2 & & 8 & 28.9 & \\
\hline Living child $>2500 \mathrm{~g}$ & 3540 & 27 & 7.6 & & 40 & 11.4 & \\
\hline
\end{tabular}


Tab. VII. Death rate per 1000 births in relation to mother's weight and height.

\begin{tabular}{|c|c|c|c|c|c|c|c|c|}
\hline & \multirow{2}{*}{$\begin{array}{l}\text { Number } \\
\text { of cases }\end{array}$} & \multicolumn{2}{|c|}{ Stillbirth } & \multicolumn{2}{|c|}{ Neonatal mortality } & \multicolumn{2}{|c|}{ Perinatal mortality } \\
\hline & & & number & ratc & number & rate & number & ratc \\
\hline \multirow{3}{*}{ Wcight } & $\leqq 45 \mathrm{~kg}$ & 511 & 6 & 11.7 & 6 & 11.9 & 12 & 23.5 \\
\hline & $46-70 \mathrm{~kg}$ & 5584 & 54 & 9.7 & 60 & 10.8 & 114 & 20.4 \\
\hline & $>70 \mathrm{~kg}$ & 360 & 9 & 25.0 & 2 & 5.7 & 11 & 30.6 \\
\hline \multirow{3}{*}{ Height } & $\leqq 150 \mathrm{~cm}$ & 478 & 2 & 4.2 & 8 & 16.8 & 10 & 20.9 \\
\hline & $151-160 \mathrm{~cm}$ & 3187 & 38 & 11.9 & 33 & 10.5 & 71 & 22.3 \\
\hline & $>160 \mathrm{~cm}$ & 2447 & 21 & 8.6 & 25 & 10.3 & 46 & 18.9 \\
\hline \multicolumn{9}{|c|}{$\begin{array}{l}\text { Variation in weight at } \\
\text { the beginning of } \\
\text { pregnancy }\end{array}$} \\
\hline & no change & 1571 & 14 & 8.9 & 18 & 11.6 & 32 & 20.4 \\
\hline & increase & 3786 & 47 & 12.4 & 43 & 11.5 & 90 & 23.8 \\
\hline & decrease & 1381 & 11 & 8.0 & 8 & 5.8 & 19 & 13.8 \\
\hline
\end{tabular}

significant difference: women who have previously had children weighing 2,500 grammes or less have a higher neonatal death rate than the reference group. We shall see later that this increased neonatal death tate is explained by a higher rate of premature births.

\subsection{Physiopathological characteristics}

\subsubsection{Mother's weight and height}

Tab. VII shows that the stillbirth rate is slightly higher for women weighing $45 \mathrm{~kg}$ or less, but chiefly for those whose weight before pregnancy was more than $70 \mathrm{~kg}$. On the contrary, neonatal death rate is not significantly related to mother's weight. The studied death rates are not related either to height or increase in weight during the first three months.

\subsubsection{Pathology in early pregnancy}

The women were very systematically questioned and their replies coded according to WHO classification. We shall refer rapidly to these results and lay stress upon the most important.

a) Infectious and parasitic diseases (influenza and thinopharyngitis excluded) are rare in pregnant women and the frequency observed in mothers of stillborn infants and infants who died during the neonatal period does not differ from that of the control group.
b) Generally diagnosed tumors are uterine

fibromyomas and tumors of the ovaries, the latter being very vaguely described by the women. There is a significant relation between fibromyomas and neonatal death rates $(81 \%$ as against $12 \%$ ).

c) Metrorrhagia during the first three months corresponds to higher rates of stillbirth and neonatal mortality, the difference being significant for perinatal mortality as a whole.

d) A study of endocrine diseases reveals a significantly higher rate of stillborn infants in diabetic women (222 per 1000). This is a well known result.

e) Serious diseases of the cardiovascular, digestive and respiratory apparatus were rare and the more frequent benign diseases are not related to perinatal mortality.

f) We found interesting associations between neurological and psychological disorders of psychosomatic type and perinatal mortality, precordial pains (numerous in mothers of infants who died in the neonatal period) and fainting (more numerous in mothers of stillborn infants) but they require verification.

\section{Discussion and synthesis}

After the first examination, it is possible to separate a group of "high risk" pregnancies. First it includes all women with a disease the role of which is well known, such as diabetes, 
fibromyoma, toxemia, heart disease. However, this group should also include women whose general characteristics and obstetrical antecedents indicate a risk of an unhappy outcome of the pregnancy. In order to predict this risk, we thought it necessary to consider stillbirth and neonatal death separately.

\subsection{Prediction of stillbirth}

The characteristics studied above do not have the same importance in the prediction of stillbirth.

a) Family status, age, parity and social class are related to stillbirth and neonatal death. The stillbirth rate varies in the porportion of $3: 1$ according to the presence or absence of these risk factors.

b) The outcome of previous pregnancies and tobacco use are principally related to stillbirth, and high risk groups can be defined by taking these two characteristics into account, in a group of 4,769 multiparous women:

1. 34 have had at least one stillborn child during their previous pregnancies and smoked at the beginning of the current pregnancy: The stillbirth rate is $235 \%$ or about 1 out of 4 .

2. 74 have had at least one child weighing $2,500 \mathrm{~g}$ or less, and smoked at the beginning of the current pregnancy: The stillbirth rate is $68 \%$ o .

3. 182 have had at least one stillborn child during their previous pregnancies and did not smoke or stopped smoking at the beginning of the current pregnancy: The stillbirth rate is $49 \%$.

These three groups as a whole represent 290 women who had 22 stillborn children, whereas there were only 30 among the other $4,479 \mathrm{mul}$ tiparous women.

We confirmed the results obtained by this analytical approach, by a global method based on the use of discriminant analysis which we applied to the prediction of stillbirth in multiparous women.

We shall not lay stress here on the methodological aspects of this analysis; it is a method of calculating the optimum ponderations of etiological characteristics in order to predict a particular condition, in our case: stillborn or alive. They are indicated in Tab. VIII and for each woman, it is possible to calculate the value of the risk function: For a married woman, over 40, belonging to a high social class it would be equal to:

$$
0.2+1.3-0.7 \ldots
$$

The higher the function the higher is the risk of stillbirth.

Tab. VIII. Stillbirth rate and coefficients given to factors by discriminant analysis method (Multiparous women).

\begin{tabular}{|c|c|c|c|c|}
\hline & & $\begin{array}{l}\text { Total } \\
4707\end{array}$ & $\begin{array}{c}\% \text { Stillbirths } \\
10.4\end{array}$ & Coefficient \\
\hline $\begin{array}{l}\text { Family status } \\
\text {. }\end{array}$ & $\begin{array}{l}\text { Unmarried } \\
\text { Married } \\
\text { Unknown }\end{array}$ & $\begin{array}{r}626 \\
4079 \\
(2)\end{array}$ & $\begin{array}{c}12.7 \\
10.0 \\
0\end{array}$ & $\begin{array}{c}-0.02 \\
0.2 \\
(-3.4)\end{array}$ \\
\hline Mother's age & $\begin{array}{l}\leqq 20 \text { years } \\
21-39 \text { years } \\
\geqq 40 \text { years } \\
\text { Unknown }\end{array}$ & $\begin{array}{r}372 \\
4181 \\
91 \\
63\end{array}$ & $\begin{array}{r}8.0 \\
9.8 \\
32.9 \\
31.7\end{array}$ & $\begin{array}{c}-0.1 \\
-0.02 \\
1.3 \\
. \quad 1.9\end{array}$ \\
\hline No. of previous pregnancies & $\begin{array}{l}<4 \\
\geqq 4\end{array}$ & $\begin{array}{r}3949 \\
758\end{array}$ & $\begin{array}{r}9.3 \\
15.8\end{array}$ & $\begin{array}{l}-0.02 \\
-0.3\end{array}$ \\
\hline Father's profession & $\begin{array}{l}1 \\
2 \\
3 \\
\text { Unknown }\end{array}$ & $\begin{array}{r}395 \\
3789 \\
371 \\
152\end{array}$ & $\begin{array}{r}2.5 \\
8.9 \\
26.9 \\
26.3\end{array}$ & $\begin{array}{c}-0.7 \\
-0.02 \\
1.8 \\
1.6\end{array}$ \\
\hline
\end{tabular}


Tab. VIII. Continuation

\begin{tabular}{|c|c|c|c|c|}
\hline & & $\begin{array}{l}\text { Total } \\
4707\end{array}$ & $\begin{array}{c}\text { \%o Stillbirths } \\
10,4\end{array}$ & Coefficient \\
\hline Mother's work outside home & $\begin{array}{l}\text { no } \\
\text { yes } \\
\text { Unknown }\end{array}$ & $\begin{array}{r}2183 \\
2482 \\
42\end{array}$ & $\begin{array}{c}9.6 \\
11.2 \\
0\end{array}$ & $\begin{array}{c}-0.02 \\
0.6 \\
-1.3\end{array}$ \\
\hline Mother's position during working hours & $\begin{array}{l}\text { Standing } \\
\text { Sitting } \\
\text { Both } \\
\text { Unknown }\end{array}$ & $\begin{array}{r}916 \\
915 \\
2666 \\
210\end{array}$ & $\begin{array}{r}8.7 \\
10.9 \\
10.8 \\
9.5\end{array}$ & $\begin{array}{l}-0.8 \\
-0.6 \\
-0.02 \\
-0.7\end{array}$ \\
\hline Tobacco use at the beginning of pregnancy & $\begin{array}{l}\text { Non smoker } \\
\text { Light smoker, no inhal. } \\
\text { Light smoker, who inhal. } \\
\text { Heavy smoker, no inhal. } \\
\text { Heavy smoker, who inhal. } \\
\text { Unknown }\end{array}$ & $\begin{array}{r}4151 \\
200 \\
93 \\
63 \\
170 \\
30\end{array}$ & $\begin{array}{r}8.1 \\
20.0 \\
43.0 \\
15.8 \\
29.4 \\
33.3\end{array}$ & $\begin{array}{c}-0.02 \\
1.0 \\
3.2 \\
0.8 \\
1.7 \\
2.8\end{array}$ \\
\hline Mother's weight & $\begin{array}{l}\leqq 45 \mathrm{~kg} \\
46-70 \mathrm{~kg} \\
\geqq 71 \mathrm{~kg} \\
\text { Unknown }\end{array}$ & $\begin{array}{r}338 \\
3668 \\
291 \\
410\end{array}$ & $\begin{array}{r}11.8 \\
9.5 \\
27.4 \\
4.8\end{array}$ & $\begin{array}{c}0.1 \\
-0.02 \\
1.5 \\
-0.5\end{array}$ \\
\hline Mother's height & $\begin{array}{l}\leqq 150 \mathrm{~cm} \\
151-170 \mathrm{~cm} \\
>170 \mathrm{~cm} \\
\text { Unknown }\end{array}$ & $\begin{array}{r}358 \\
3749 \\
87 \\
513\end{array}$ & $\begin{array}{c}5.5 \\
10.2 \\
0 \\
17.5\end{array}$ & $\begin{array}{l}-0.5 \\
-0.02 \\
-0.9 \\
0.8\end{array}$ \\
\hline $\begin{array}{l}\text { Weight variation at the beginning of } \\
\text { pregnancy }\end{array}$ & $\begin{array}{l}= \\
+ \\
\overline{\text { Unknown }}\end{array}$ & $\begin{array}{r}1059 \\
2560 \\
874 \\
214\end{array}$ & $\begin{array}{r}8.4 \\
12.5 \\
6.8 \\
9.3\end{array}$ & $\begin{array}{c}-0.02 \\
0.2 \\
-0.3 \\
0.1\end{array}$ \\
\hline Rhesus & $\begin{array}{l}- \\
\frac{1}{+} \\
\text { Unknown }\end{array}$ & $\begin{array}{r}836 \\
3567 \\
304\end{array}$ & $\begin{array}{l}10.7 \\
10.0 \\
13.1\end{array}$ & $\begin{array}{l}0.1 \\
-0.02 \\
-0.2\end{array}$ \\
\hline Miscarriages & $\begin{array}{l}\text { No } \\
\text { Yes }\end{array}$ & $\begin{array}{l}3211 \\
1496\end{array}$ & $\begin{array}{r}8.0 \\
15.3\end{array}$ & $\begin{array}{c}-0.02 \\
0.9\end{array}$ \\
\hline Stillborn infants & $\begin{array}{l}\text { No } \\
\text { Yes }\end{array}$ & $\begin{array}{r}4498 \\
209\end{array}$ & $\begin{array}{r}7.5 \\
71.7\end{array}$ & $\begin{array}{c}-0.02 \\
3.1\end{array}$ \\
\hline Premature infants & $\begin{array}{l}\text { No } \\
\text { Yes }\end{array}$ & $\begin{array}{r}3819 \\
888\end{array}$ & $\begin{array}{r}7.5 \\
22.5\end{array}$ & $\begin{array}{c}-0.02 \\
0.3\end{array}$ \\
\hline Low birth weight infants & $\begin{array}{l}\text { No } \\
\text { Yes }\end{array}$ & $\begin{array}{r}4071 \\
636\end{array}$ & $\begin{array}{r}8.3 \\
29.5\end{array}$ & $\begin{array}{c}-0.02 \\
0.9\end{array}$ \\
\hline Outcome of the last pregnancy & $\begin{array}{l}\text { Miscarriage } \\
\text { Stillborn } \\
\text { Living }<2500 \mathrm{~g} \\
\text { Living } 2500-4000 \mathrm{~g} \\
\text { Living }>4000 \mathrm{~g} \\
\text { Living wt. unknown }\end{array}$ & $\begin{array}{r}893 \\
98 \\
275 \\
3108 \\
259 \\
74\end{array}$ & $\begin{array}{r}12.3 \\
102.0 \\
14.5 \\
6.7 \\
15.4 \\
0\end{array}$ & $\begin{array}{c}-0.4 \\
5.6 \\
-0.6 \\
-0.02 \\
0.7 \\
-1.0\end{array}$ \\
\hline Metrorrhagia during the first 3 months & $\begin{array}{l}\text { No } \\
\text { Yes }\end{array}$ & $\begin{array}{r}4010 \\
697\end{array}$ & $\begin{array}{r}9.7 \\
14.3\end{array}$ & $\begin{array}{c}-0.02 \\
0.2\end{array}$ \\
\hline
\end{tabular}


Tab. VIII leads to several comments:

a) Firstly, the very high coefficient of the existence of stillborn children in the case history, which completely confirms our conclusions.

b) Then, good agreement between the coefficients and the results given above.

c) Finally, high ponderations given to nonspecified replies, which we could explain easily if they always were positive coefficients, for it might be supposed that the non specified replies came from women with little French, who had a high risk of stillbirth. But the coefficients are often negative, taking on a relatively important prospective role that we have not yet explained. However, we should like to emphasize the fact that the results given in Tab. VIII are merely for indicatory purpose. We consider that the number of stillborn infants is too low for a discriminating analysis to be applied strictly.

We calculated the value of the risk function for each woman and give the distribution of the function separately for the mothers of stillborn children and those with live-born children. The two curves are rather well separated and we have divided the population into three groups, according to the value of the function:

\section{Summary}

This study submits ways of predicting stillbirth and neonatal death based on characteristics recorded in early pregnancy. It is based on a prospective survey carried out by the Maternity and Pediatric Section of I. N. S. E. R. M. in collaboration with the Statistical Research Unit of I. N. S. E. R. M. and the Obstetric Departments of Hospitals of the Assistance Publique in Paris. This survey included an examination and a detailed interview during the first three months, systematic examination of the newborn infant and follow-up of some groups of children during their first year.

The analysis covered 7,032 women born in France who had not had a twin pregnancy. In the first part, the authors examined the prognostic role of each factor. The second part is a global study of the factors as a whole by discriminant analysis.

The results confirm some findings: family status, age, number of previous pregnancies are very obviously related to stillbirth and neonatal death (Tab. I). Unwed mothers have a higher perinatal death rate $(33.2 \%)$ than married women $(17.9 \%$ ) (Tab. II); there is a significant difference for neonatal mortality. Concerning maternal age, rate of stillbirths and neonatal mortality are higher a) $\leqq 2.2$ : low risk group - stillbirth rate: 5 per 1.000 ( 3,854 women)

b) 2.3 to 6.4 : intermediate group - stillbirth rate: 29 per 1,000 (376 women)

c) $>$ 6.4: high risk group - stillbirth rate: 85 per 1.000 (211 women).

\subsection{Prediction of neonatal death}

This proves much more difficult at the beginning of pregnancy, which may be easily understood if we remember that the most discriminant characteristics of stillbirth (tobacco, history of stillborn children) are not related to neonatal mortality. This also corroborates the results we obtained elsewhere, that is, the difficulties in predicting prematurity at the beginning of pregnancy. As a matter of fact, prematurity is known to be one of the main causes of neonatal mortality.

This leads us to emphasize the dangers one might encounter in carrying out research on perinatal mortality as a whole, without dissociating neonatal mortality, and stillbirth.

for mothers older than 30 (Tab. III). On the other hand, one can notice a higher rate of stillbirths as well as a higher rate of neonatal mortality in women with a higher number of previous pregnancies. These two characteristics, age and parity, being related to one another, it has been verified that each one has its own predictive value. The social and professional status also has an influence, especially on mortinatality: This rate is $5.4 \%$ for the executive class, and $20.9 \%$ for unskilled laborers and service staff (Tab. IV).

Other results, however, have a more original character: the stillbirth rate is much higher for mothers who continue to smoke during the first three months of pregnancy $(27.9 \%, 8.6 \%$ for non smokers, and $2.9 \%$ for smokers who stopped smoking at the beginning of their pregnancy) (Tab. V), and this is confirmed when smokers and nonsmokers are made comparable for all the characteristics that differentiate them in the study; the number of cigarettes smoked is not related to the stillbirth rate, but inhaling the smoke is: $14.1 \%$ for smokers who don't inhale, $38.9 \%$ for those who do so. A more careful study shows that the effect of tobacco is principally shown in women with serious obstetrical case history. 
Among women who had at least one still-birth in the past, those who smoke have a mortinatality rate of $235 \%$ compared with $49 \%$ for those who don't smoke at the beginning of pregnancy. On the contrary, neonatal mortality is not related to the use of tobacco during pregnancy.

The study of the physiopathological characteristics of the mother confirms some relations known to exist between the stillbirth rate, the mother's weight, the existence of uterine fibromyoma or diabetes: In our study, for women weighing more than $70 \mathrm{~kg}$, the mortinatality rate is as high as $25 \%, 81 \%$ for mothers with fibromyomas, $222 \%$ for diabetic mothers. Two less usual associations should be referred to, metrorrhagia during the first three months of pregnancy is more frequent in mothers of stillborn infants, who also have more pronounced psycho- somatic signs (precordial pains, fainting) at the time of the interview in the third month.

All thesc characteristics were taken into account simultaneously in a discriminant analysis, performed on the sample of multiparous women in order to include information on the obstetrical history (Tab. VIII). This analysis points out as the most predictive characteristics those with the highest coefficients, which is in agreement with the previous results. This method permits a definition of groups with increasing risk: In the high risk group, the observed mortinatality rate is $85 \%$, and it is $5 \%$ in the low risk group. However, prediction of neonatal mortality at the beginning of pregnancy proves more difficult, like that of prematurity, which is one of its principal causes.

Keywords: Maternal factors, multiple regression, perinatal mortality, prediction, previous pregnancies, tobacco use.

\section{Zusammenfassung}

Voraussage der Geburtensterblichkeit in der Frühschwangerschaft

Die vorliegende Studie arbeitet die Richtlinien für eine Vorhersage von einer Totgeburt und eines Todes in der Neugeborenenzeit anhand von Kriterien aus, die in der Frühschwangerschaft aufgezeichnet werden. Sie basiert auf einer prospektiven Untersuchung, die von der Sektion Maternite-Pediatrie der I. N. S. E. R. M. in Zusammenarbeit mit dem statistischen Untersuchungsamt der I. N. S. E. R. M. und der geburtshilflichen Abteilungen der Krankenhäuser von Paris durchgeführt wurde. Diese Studie schließt eine Untersuchung und eine genaue Befragung während der ersten 3 Monate, eine systematische Neugeborenenuntersuchung und eine, Betreuung einiger Gruppen von Kindern während des ersten Lebensjahres ein.

Die Analyse erstreckt sich auf 7032 Frauen, die in Frankreịch geboren sind und die noch keine $Z$ willingsgeburt hatten. Zuerst untersuchten die Autoren die prognostische Bedeutung jedes Faktors. Der zweite Teil ist eine Gesamtstudie der Faktoren insgesamt durch eine Diskriminanzanalyse.

Die Ergebnisse bestätigen einige berẻits bekannte Tatsachen, daß nämlich zwischen der Familienanamnese, dem Alter, der Zahl der früheren Schwangerschaften einerseits (Tab. I) und der Totgeburt und einem Tod im Neugeborenenalter andererseits ein Zusammenhang besteht. Unverheiratete Mütter weisen eine höhere perinatale Todesrate $(33,2 \%)$ auf als verheiratete Frauen $(17,9 \%$ ) (Tab. II). Einen signifikanten Unterschied gibt es nur für die Neugeborenensterblichkeit. Die Zahl der Totgeburten und die Neugeborenensterblichkeit sind höher bei Müttern über 30 Jahren (Tab. III). Andererseits steht die Rate von Totgeburten und der Neugeborenensterblichkeit in Beziehung zur Anzahl der vorausgegangenen Schwangerschaften. Beim Vergleich der beiden Charakteristika Alter und Geburtenhäufigkeit wurde festgestellt, daß jedes von beiden seinen eigenen Voraus- sagewert besitzt. Auch der soziale und berufliche Stand haben einen Einfluß, besonders auf die Zahl der Totgeburten. Diese Rate beträgt $5,4 \%$ für die obere Schicht und $20,9 \%$ für die untersten sozialen Schichten (Tab. IV). Andere Ergebnisse ergeben jedoch neue Gesichtspunkte: Die Rate der Totgeburten ist bei Müttern höher, die während der ersten 3 Schwangerschaftsmonate rauchen $(27,9 \%$, im Vergleich dazu $8,6 \%$ bei Nichtraucherinnen und 2,9\% für Raucherinnen, die mit Beginn der Schwangerschaft das Rauchen aufgaben) (Tab. V) und dies wird bestätigt, wenn Raucherinnen und Nicht-Raucherinnen verglichen werden in allen Charakteristika, die sie in der Studie unterscheiden. Die Menge der Zigaretten steht zwar nicht in Beziehung zur Höhe der Totgeburten, die Totgeburtenrate beträgt jedoch $14,1 \%$ für Raucherinnen, die nicht inhalieren, und 38,9\% für diejenigen, die inhalieren. Eine genauere Studie zeigt, daß die Wirkung des Rauchens besonders bei Frauen in Erscheinung tritt, bei denen Geburten mit Komplikationen vorangegangen sind. Unter den Frauen, die eine Totgeburt bereits hatten, hatten die Raucherinnen eine Totgeburtenrate von $235 \%$, während sie $49 \%$ bei den Frauen betrug, die mit Beginn der Schwangerschaft nicht rauchten. Im Gegensatz dazu steht die Neugeborenensterblichkeit in keiner Beziehung zum Rauchen.

Die Studie der pathophysiologischen Charakteristika der Mutter bestätigt einige bekannte Zusammenhänge, die zwischen der Rate der Totgeburten, dem Gewicht der Mütter und einem Fibromyom des Uterus oder einem Diabetes bestehen: in unserer Studie beträgt die Rate der Totgeburten $25 \%$ bei Frauen, die mehr als $70 \mathrm{~kg}$ wiegen, $81 \%$ für Mütter mit Fibromyomen und $222 \%$ für diabetische Mütter. Zwei weniger häufige Kombinationen sollen erwähnt werden. Eine Metrorrhagie während der ersten 3 Schwangerschaftsmonate ist häufiger bei Müttern mit Totgeburten anzutreffen, die auch psychosomatische Erscheinungen zum Zeitpunkt der Befragung im 3. Monat hatten. 
All diese Charakteristika wurden gleichzeitig durch Diskriminanzanalyse in Beziehung gesetzt, die bei den Multipara durchgeführt wurde, um eine Information über die Geburtsgeschichte $\mathrm{zu}$ erhalten (Tab. VIII). Die Analyse stellt diejenigen Charakteristika als solche mit höchstem Voraussagewert dar, die die höchsten Koeffizienten haben, was mit früheren Ergebnissen über- einstimmt. Diese Methode érlaubt eine Aufstellung von Gruppen mit erhöhtem Risiko: In der Gruppe mit höchstem Risiko beträgt die Totgeburtenrate $85 \%$ und in der Gruppe mit dem geringsten Risiko $5 \%$. Jedoch erweist sich die Voraussage der Neugeborenensterblichkeit beim Schwangerschaftsbeginn schwieriger als die der Frühgeburt, welche eine ihrer Hauptursachen ist.

Schlüsselwörter: Mortalität (perinatale), mütterliche Faktoren, Rauchen, Schwangerschaften (frühere), Voraussage)

\section{Résumé}

Prévision de la mortalité périnatale en début de grossesse

Cẹtte étude établit une prévision de la mortinatalité et de la mortalité néo-natale à partir des caractères enregistrés ien début de grossesse. Elle a été réalisée dans le cadre d'une enquête prospective conduite par la Section Maternité-Pédiatrie de l'I. N. S. E. R. M., en collaboration avec l'Unité de Recherches Statistiques de l'I. N. S. E. R. M. et les Services d'Obstétrique des Hôpitaux de l'Assistance Publique de Paris. Cette enquête comportait un examen et un interrogatoire détaillé au cours du premier trimestre, un examen systématique du nouveau-né et une surveillance de certain groupes au cours de la première année.

L'analyse porte sur 7032 femmes nées en France et ayant eu une grossesse uni-gémellaire. Elle comporte deux parties. Dans un premier temps, les auteurs examinent le rôle pronostique de chaque facteur, dans un deuxième temps, ils réalisent une étude simultanée de l'ensemble des facteurs, au moyen d'une analyse discriminante.

Les résultats confirment un certain nombre de données: la situation de famille, l'âge, le nombre de grossesses antérieures sont liées à la mortinatalité et à la mortalité néo-natale de façon très nette (Tab.I). Chez les mères célibataires le taux de mortalité périnatale $(33,2 \%)$ est plus élevé que chez les femmes mariées $(17,9 \%)$ (Tab. II); la différence est significative pour la mortalité néo-natale. En ce qui concerne l'âge de la mère, il y a un excès de mortinatalité et de mortalité néo-natale chez les mères de plus de 30 ans (Tab. III). D'autre part, on relève une augmentation du taux de mortinatalité aussi bien que du taux de mortalité néo-natale en fonction du nombre de grossesses antérieures. Ces deux caractères, âge et parité, étant liés, il a été vérifié que chacun avait une valeur prédictive propre. La situation socio-professionnelle intervient aussi, mais surtout sur la mortinatalité: ce taux est de $5,4 \%$ dans la classe la plus élevée, et de $20,9 \%$ dans la classe la plus basse (Tab. IV).

D'autres résultats par contre, présentent un caractère plus original: la mortinatalité est nettement plus importante pour les mères qui continuent à fumer au cours du premier trimestre de la grossesse $(27,9 \%$ alors qu'il est de $8,6 \%$ chez les non fumeuses habituelles et de $2,9 \%$ chez les fumeuses qui ont arrêté de fumer en début de grossesse. (Tab. V); cette différence se confirme lorsqu'on rend fumeuses et non fumeuses comparables pour tous les caractères les différenciant dans l'enquête; la quantité fumée n'est pas liée à la mortinatalité, mais l'inhalation lui est liée: $14,1 \%$ chez les femmes qui n'inhalent pas, $38,9 \%$ chez celles qui inhalent. Une étude plus approfondie montre que l'effet du tabac se manifeste essentiellement chez les femmes ayant eu des antécédents obstétricaux graves. Parmi les femmes ayant eu au moins un mort-né au cours de leurs grossesses passées, celles qui fument ont un taux de mortinatalité de $235 \%$, alors que pour celles qui ne fument pas ou ont cessé de fumer en début de grossesse, ce taux est de $49 \%$. La mortalité néonatale, par contre, n'est pas liée à l'usage du tabac au cours de la grossesse.

L'étude des caractères physio-pathologiques de la mère confirme certaines relations connues entre la mortinatalité, le poids de la mère, l'existence d'un fibromyome utérin ou d'un diabète: dans notre étude, chez les femmes pesant plus de $70 \mathrm{~kg}$, le taux de mortinatalité s'élève à $25 \%$, $81 \%$ chez les mères porteuses de fibromyome, $222 \%$ chez les mères diabétiques. Deux associations moins classiques sont à signaier, les métrorragies du premier trimestre de la grossesse sont plus fréquentes chez les mères des mort-nés et celles-ci accusent davantage de manifestations psychosomatiques (douleurs précordiales, syncopes) lors de l'interrogatoire du troisième mois.

La prise en compte simultanée de tous ces caractères dans une analyse discriminante (Tab. VIII) réalisée chez les femmes multigestes pour utiliser l'information concernant les antécédents obstétricaux, permet de faire ressortir les caractères les plus prédictifs, qui se voient affectés d'un coefficient élevé, ce qui confirme les résultats précédemment cités. Cette méthode a permis de définir des groupes de risque croissant: dans le groupe à haut risque, le taux de mortinatalité observé est de $85 \%$, contre $5 \%$ dans le groupe à bas risque. Par contre, la prévision de la mortalité néo-natale en début de grossesse s'avère plus difficile, ainsi d'ailleurs que celle de la prématurité qui est une de ses principales composantes.

Mots-clés: Facteurs maternels, grossesses anterieures, mortalité périnatale, prévision, régression multiple, usage du tabac. 


\section{Bibliography}

[1] Drouhet, V., C. Rouquette: Dépistage sérologique des infections inapparentes par les virus Coxsackies B au cours de la grossesse chez les méres des malformés et chez celles des enfants normaux. Bull. l'I. N. S. E. R. M. 25 (1970) 29

[2] Kaminski, M., J. Goujard, C. Rumeau-Rouquette: Prediction of low birth weight and prematurity by a multiple regression analysis with maternal characteristics known since the beginning of the pregnancy. Intern. J. Epidemiol. 2 (1973) 195

[3] Rouquette, C., M. M. Guyot, A. Bodoutchian, F. Garnier, A. Bricet: Données concernant la rubéole au cours de la grossesse. Rev. Prat. 14 (1969) 67

[4] Rouquette, C., Ch. Chany, G. Desmonts, V. DrouHET: Recherches virales dans le cadre de l'Enquête prospective de l'I. N. S. E. R. M. 3rd International
Conference on Congenital Malformations, The Hague 1969

[5] Rouquette, C., D. Schwartz: Méthodes en Epidémiologie. Flammarion, Paris 1970

[6] Rumeau-Rouquette, C., J. Goujar.d, C. Etienne: Relation entre les métrorragies du début de la grossesse et les malformations congénitales. Gyn. Obst. 70 (1971) 557

[7] Rumenu-Rouquette, C., J. Goujard, M. Kaminski, D. Schwartz: Mortalité périnatale, Antécédents obstétricaux et usage du tabac. Journ. Gyn. Obst. Biol. Repr. 1 (1972) 723

[8] Spira, N., J. Goujard, G. Huel, C. Rumeau-RouQUETTE: Etude du role tératogene des hormones sexuelles: premiers résultats d'une enquete épidémiologique portant sur 20000 femmes. Rev. Med. 41 (1972) 2683
Dr. C. Rumeau-Rouquette Section Maternité-Pédiatrie 44 Chemin de Ronde F-7810 Le Vésinet/France 